\title{
ESTABLISHMENT OF SERRATIA ENTOMOPHILA AFTER APPLICATION OF A NEW FORMULATION FOR GRASS GRUB CONTROL
}

\author{
R.J. TOWNSEND ${ }^{1}$, C.M. FERGUSON ${ }^{1}$, J.R. PROFFITT ${ }^{1}$, \\ M.W.A. SLAY ${ }^{2}$, J. SWAMINATHAN ${ }^{1}$, S. DAY ${ }^{1}$, E. GERARD ${ }^{1}$, \\ M. O'CALLAGHAN ${ }^{1}$, V.W. JOHNSON ${ }^{1,3}$ and T.A. JACKSON ${ }^{1}$ \\ ${ }^{1}$ Biocontrol and Biosecurity Group, AgResearch, PO Box 60, Lincoln \\ ${ }^{2}$ Homelea Ltd, Shanley Road, RD 9, Hastings \\ ${ }^{3}$ Present address; Biodiscovery Ltd, 24 Balfour Road, Parnell, Auckland \\ Corresponding author: richard.townsend@agresearch.co.nz
}

\begin{abstract}
The bacterium Serratia entomophila is a naturally occurring pathogen causing amber disease of the New Zealand grass grub (Costelytra zealandica). A novel granular formulation of S. entomophila, Bioshield ${ }^{\mathrm{TM}}$, was applied to 18 pasture sites in a large-scale programme to demonstrate efficacy against grass grub. No significant difficulties were encountered in application of the granules through conventional machinery. There were high populations of the applied bacteria in soil within the first week of application, and within 6 weeks of application there was an average of $3 \times 10^{4}$ viable $S$. entomophila, of the applied strain, per gram of soil. This resulted in a significant $(\mathrm{P}<0.05) 20 \%$ increase in the incidence of amber disease in the treated grass grub populations compared to untreated populations. Successful establishment of the bacteria in the soil and target population following Bioshield ${ }^{\mathrm{TM}}$ granule application was demonstrated on a wide range of sites under various farming conditions.
\end{abstract}

Keywords: Serratia entomophila, grass grub, granule, biopesticide, efficacy.

\section{INTRODUCTION}

The grass grub (Costelytra zealandica (White), Coleoptera: Scarabaeidae) is a persistent pest of New Zealand pastures and can cause extensive damage through larval feeding on the roots of grasses and clovers. Grass grub can be controlled by application of the bacterium Serratia entomophila (Jackson et al. 1992), which has been applied as the commercial product Invade ${ }^{\mathrm{TM}}$ since 1990 . The Invade product was a liquid formulation with the disadvantages that it had to be stored at $4-5^{\circ} \mathrm{C}$ and applied through specialised machinery (modified seed drills) with a high rate of water (100 litres/ha). These restrictions have limited use of the bacteria and to improve product uptake, research has concentrated on development of a thermostable granular formulation of the bacteria (Johnson et al. 2001).

A prototype granule, Bioshield ${ }^{\mathrm{TM}}$, has now been developed. This was tested for grass grub control efficacy on farms across a wide range of farming locations and conditions throughout New Zealand. The early results of these tests are presented in this paper.

\section{METHODS}

Eighteen pastures from six grass grub-prone regions throughout New Zealand were selected after discussion between Ballance Agri-Nutrients field staff and AgResearch staff (Table 1). The sites represented a range of grazing scenarios (dairy, sheep, beef, sheep and beef, or deer grazing) and had potential grass grub problems with populations ideally in the range of 100-350 grass grubs $(\mathrm{gg}) / \mathrm{m}^{2}$, although there were some sites 
with higher populations. Grass grub populations were estimated by taking a minimum of ten $15 \times 15 \mathrm{~cm}$ spade divots per treated and untreated areas on each site, and disease status pre-treatment was determined by visual examination. Soil samples (forty $2.5 \mathrm{~cm}$ x $8 \mathrm{~cm}$ cores) were taken to assess the levels of background Serratia spp. on each site prior to treatment with Bioshield ${ }^{\mathrm{TM}}$ granules.

TABLE 1: Region and site details for application of Bioshield ${ }^{\mathrm{TM}}$ granules. $^{-}$

\begin{tabular}{lclc}
\hline Region & No. sites & Grazing type & Initial gg/m $\mathrm{m}^{2}$ \\
\hline Taupo & 2 & both deer & $205-255$ \\
Hawke's Bay & 1 & sheep and beef & 293 \\
Manawatu & 1 & sheep and beef & 143 \\
Taranaki & 2 & both dairy & $117-230$ \\
Canterbury - coastal & 7 & 3 sheep and beef, 3 deer, 1 sheep & $167-263$ \\
Canterbury - other & 2 & 1 sheep, 1 sheep and beef & $298-486$ \\
Southland & 3 & all sheep & $261-782$ \\
\hline
\end{tabular}

Serratia entomophila 154 was produced by fermentation and formulated as a biopolymer-coated granule, Bioshield ${ }^{\mathrm{TM}}$. The granules were bagged in $15 \mathrm{~kg}$ units, distributed and stored under normal warehouse conditions prior to use. At each site, a paddock, or an area of pasture of at least 2 ha, was treated during late March and early April 2003 with Bioshield ${ }^{\mathrm{TM}}$ granules containing approximately 1 x $10^{9}$ viable S. entomophila cells $/ \mathrm{g}$ at a rate of $30 \mathrm{~kg} / \mathrm{ha}$. An equivalent adjacent paddock or 2 ha area within the treated paddock was selected to use as a comparative untreated pasture. The granules were drilled into the pasture to a depth of $2-3 \mathrm{~cm}$ by farmers or contractors using a variety of standard seed drills. A sample of granules was collected from the drill during application at each site and assessed for bacterial viability by dilution plate counting and enumeration on selective agars (O'Callaghan \& Jackson 1993) to determine the effect of a range of storage and transport conditions.

Within one week of application, 40 soil samples were taken from the drill rows, and S. entomophila enumerated as described above. The applied strain could be identified by phage typing (O'Callaghan et al. 1997). At six weeks post application, random soil samples were collected from treated and untreated areas at each site to assess levels of establishment and survival of the bacteria applied in the Bioshield ${ }^{\mathrm{TM}}$ granules. Grass grub larvae were also collected, a minimum of 30 intact larvae from a minimum of 6 different locations within the treated and untreated areas at each site. Grass grub samples from all sites were assessed in the laboratory to determine the level of amber disease in the grass grub populations on each site (Jackson et al.1997). Treatment effects were determined by Genstat 6.1 regression analysis.

\section{RESULTS}

Grass grub populations in pastures prior to treatment averaged $283 / \mathrm{m}^{2}$, ranging from 117 to 782 larvae $/ \mathrm{m}^{2}$. Samples taken from the drill at time of application averaged $1.46 \times 10^{9}$ viable $S$. entomophila/g granule. Serratia entomophila strain 154 was isolated from drill rows of all treated pastures with an average of $7.6 \times 10^{5} \mathrm{~S}$. entomophila/g soil (range: $2.7-34.6 \times 10^{5}$ ) recovered. This strain was only isolated from three of the untreated pastures, all in Canterbury, where it occurred at low levels. Six weeks post application, random, off-row soil sampling showed a good level of bacterial establishment with an average of $3 \times 10^{4} \mathrm{~S}$. entomophila/g soil. This is sufficient to initiate a cycle of amber disease in the grass grub population (O'Callaghan et al. 1999). Visual examination of grass grub larvae indicated that the average level of disease in the treated plots 6 weeks after treatment with granules was $24 \%$, significantly $(\mathrm{P}<0.001)$ greater than the $7 \%$ disease in the untreated populations. The highest levels of disease in untreated reference pastures were located on two 'coastal' Canterbury sites which both had a high incidence of natural pathogenic bacteria (Fig. 1). Statistical analysis of results from all sites showed 
that the underlying effect of the bacterial treatment was a $20 \%(\mathrm{P}<0.05)$ increase in amber diseased grass grub larvae over and above the observed background levels.

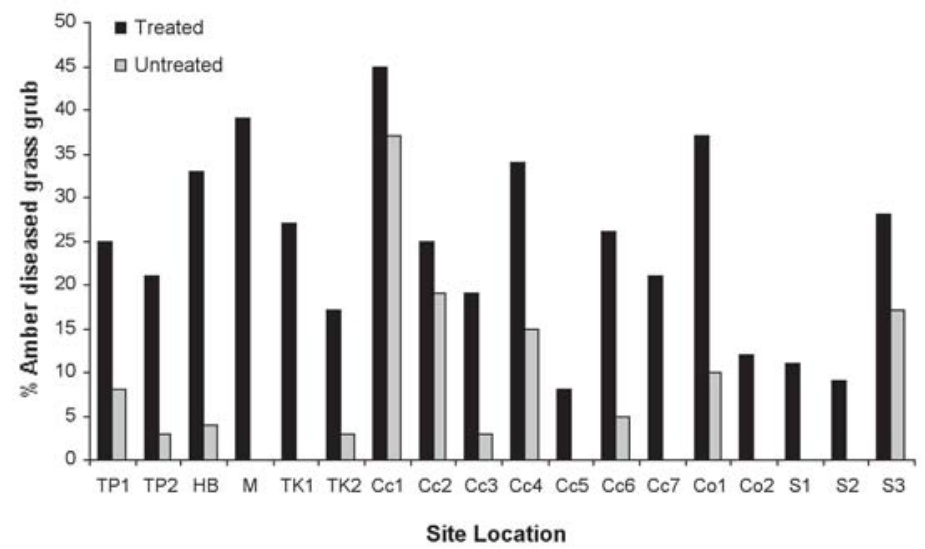

FIGURE 1: Percentage amber disease in grass grub larvae sampled from the paired treated and untreated pasture sites 6 weeks after application of Bioshield $^{\mathrm{TM}}$ granules.

Scrutiny of disease levels at different sites and between regions gave no indication of differences in regional response to bacterial application. Lower levels of disease on two of the Southland sites could have resulted from a high proportion of two-year life cycle larvae in those populations, which meant that lower numbers of feeding larvae were present through the assessment period of mid to late May. A full explanation of two-year grass grub lifecycle dynamics in Southland is given in Barratt et al. (1990). However the other Southland site showed high levels of disease, and some variation in disease uptake occurred in all regions which could have been the result of intrinsic paddock factors, such as age and feeding status of the grass grub population, or simply sampling variation.

\section{DISCUSSION}

The level of viable $S$. entomophila recovered from the granules taken from the seed drills at the point of application was close to the manufacturing average and indicated that bacteria had been stabilised within the formulation with minimal mortality despite a range of distribution and storage conditions. The granules handled well at the point of application and no significant problems were reported by the applicators, despite a wide variety of seed drills being used for delivery to the soil. Viability of the bacteria in the granules was confirmed by a high level of recovery of the applied bacteria from the soil with population estimation aided by the relatively low natural abundance of bacteria corresponding to the applied strain type (154) of S. entomophila on the treated sites. An estimated $3 \times 10^{4}$ S. entomophila $154 / \mathrm{g}$ soil after 6 weeks represents $70 \%$ of applied cells, indicating that that the applied bacteria were able to survive the initial phase of establishment within the pasture soil environment.

To cause disease, the applied bacteria must be ingested by the feeding grass grub larvae. As the bacteria are drilled in distinct rows, at $15 \mathrm{~cm}$ spacings, it may be some time before the larvae furthest from the drill row at application are in contact with the bacteria. However, larval assessment after 6 weeks showed a statistically significant 
$20 \%$ increase in disease levels indicating that a substantial number of larvae had come into contact with the applied bacteria. Levels of disease of between 15 and $20 \%$ within two months of treatment are considered a preliminary indicator of the success of application. It has been shown that this level of disease indicates establishment of a disease epizootic in the target population and will cause a subsequent decease in the grass grub population (Jackson et al. 1992).

Bacterial establishment showed little variation across the different regions suggesting that there are few soil factors antagonistic to the establishment of the bacteria. Some variability was observed in the level of disease caused in different grass grub populations but there were no consistent trends related to region or pasture management. Previous results suggest that this variability is related to individual site factors, such as soil moisture levels and grass grub population characteristics, or sampling variability.

The granule formulation of Bioshield ${ }^{\mathrm{TM}}$ appears to have resulted in successful establishment of the bacteria and disease in the target grass grub populations. Bacterial establishment and early disease responses are similar to those recorded for the liquid formulation. There may be an additional benefit when pasture is treated under dry conditions; bacteria formulated within the granule are more persistent than unformulated bacteria (O'Callaghan et al. 2001). A major benefit of the stable granule formulation is its flexibility for users since it can be distributed, stored and applied without special equipment and without loss in viability and efficacy of $S$. entomophila.

\section{ACKNOWLEDGEMENTS}

This research was supported by Ballance Agri-Nutrients and the New Zealand Foundation for Research, Science and Technology Biopesticides programme. Our thanks to the farmers who took part in the study and Ballance commercial staff for their input. Our thanks also to Dave Saville for statistical analysis.

\section{REFERENCES}

Barratt, B.I.P.; van Toor, R.F.; Ferguson, C.M.; Stewart, K.M. 1990: Grass grub and porina in Otago and Southland: a guide to management and control. Tablet, Dunedin, New Zealand. Pp. 1-8.

Jackson, T.A.; Pearson, J.F.; O'Callaghan, M.; Mahanty, H.K.; Willocks, M. 1992: Pathogen to product - development of Serratia entomophila (Enterobacteriaceae) as a commercial biological control agent for the New Zealand grass grub (Costelytra zealandica). In: Jackson, T.A.; Glare T.R. ed. Use of Pathogens in Scarab Pest Management. Intercept, Andover, UK. Pp. 191-198.

Jackson, T.A.; Townsend, R.J.; Nelson, T.L.; Richards, N.K.; Glare, T.R. 1997: Estimating amber disease in grass grub populations by visual assessment and DNA colony blot analysis. N.Z. Plant Prot. 50: 165-168.

Johnson, V.W.; Pearson, J.F.; Jackson, T.A. 2001: Formulation of Serratia entomophila for biological control of grass grub. N. Z. Plant Prot. 54: 125-127.

O'Callaghan, M.; Jackson, T.A. 1993: Isolation and enumeration of Serratia entomophila - a bacterial pathogen of the New Zealand grass grub, Costelytra zealandica. J. Appl. Bact. 75: 307-314.

O’Callaghan, M.; Jackson, T.A.; Glare, T.R. 1997: Serratia entomophila bacteriophages - host range determination and preliminary characterisation. Can. J. Microbiol. 43: 1069-1073.

O’Callaghan, M.; Young, S.D.; Barlow, N.D.; Jackson, T.A. 1999: The ecology of grass grub pathogenic Serratia spp. in New Zealand pastures. Proc. 7th Australasian Conf. Grassland Invert. Ecol.: 85-91.

O’Callaghan, M.; Gerard, E.M.; Johnson, V.W. 2001: Effect of soil moisture and temperature on the survival of microbial control agents. N.Z. Plant Prot. 54: $128-135$. 